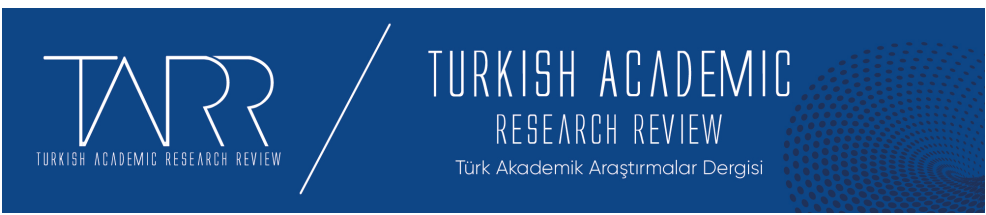

e-ISSN: 2602-2923

Yıl/Year: $2020 \quad$ Cilt/Volume: $5 \quad$ Sayı/Issue: 3

Alevî-Bektâşî İnanç Sisteminde Hayvanlarla İlgili Mitolojik Unsurlar

Mythological Elements About Animals In The Alevi-Bektashi Belief System

Salih Emre Karayel - Ali Albayrak

Doktorant, Akdeniz Üniversitesi Sosyal Bilimler Enstitüsü Doktora Öğrencisi, emrehey@hotmail.com, Orcid: 0000-0002-0272-135X

Doç. Dr., Akdeniz Üniversitesi İlahiyat Fakültesi Felsefe ve Din Bilimleri Bölümü Din Sosyoloji ABD, alialbayrak@akdeniz.edu.tr, Orcid: 0000-0003-0558-2612

\begin{tabular}{r|l} 
Makale Bilgisi & Article Information \\
Makale Türü - Article Type & Araştırma Makalesi / Research Article \\
Geliş Tarihi - Date Received & 7 Ağustos / August 2020 \\
Kabul Tarihi - Date Accepted & 25 Eylül / September 2020 \\
Yayın Tarihi - Date Published & 30 Eylül / September 2020 \\
Yayın Sezonu & Temmuz - Ağustos - Eylül \\
Pub Date Season & July - August - September
\end{tabular}

Atıf / Cite as: Karayel, Salih Emre-Albayrak, Ali, Alevî-Bektâşî İnanç Sisteminde Hayvanlarla İlgili Mitolojik Unsurlar/Mythological Elements About Animals In The Alevi-Bektashi Belief System. tarr: Turkish Academic Research Review, 5 (3), 438455. doi: tarr. 777986.

Intihal / Plagiarism: Bu makale, en az iki hakem tarafından incelenmiş ve intihal içermediği teyit edilmiştir. / This article has been reviewed by at least two referees and confirmed to include no plagiarism. https://dergipark.org.tr/tr/pub/tarr

Copyright (C) Published by Mehmet ŞAHIN Since 2016- Akdeniz University, Faculty of Theology, Antalya, 07058 Turkey. All rights reserved.

Turkish Academic Research Review - Türk Akademik Araştırmalar Dergisi https://dergipark.org.tr/tr/pub/tarr 


\title{
Alevî-Bektâşî İnanç Sisteminde Hayvanlarla İlgili Mitolojik Unsurlar $^{1}$
}

\author{
Salih Emre Karayel - Ali Albayrak
}

\begin{abstract}
Özet
Mitoloji, insanlığın genel anlamda evreni anlama ve anlamlandırma bağlamında ortaya koyduğu ürünler olarak ifade edilir. İçeriğinde hayal ürünü unsurları barındıran, bununla birlikte gücünü gerçekle olan bağlantısından alan mitler, içinden çıktığı toplumun kültür hazinesinin temel taşlarını oluşturarak, bireylerin milli bilince ulaşmasında önemli işlevler üstlenmişlerdir. Sosyal ve kültürel birer olgu olarak karşımıza çıkan mitler, toplumların sosyal ve dini yaşamında varlığını bir şekilde hissettirmeyi başarmışlardır. Şüphesiz içinde inanç unsurları ve dini ögeleri barındırması ve yaşadığı dönem itibariyle "kutsal" ve "gerçek" kabul edilmesi sebebiyle mitler, toplum hayatının şekillenmesinde bir başka önemli unsur olan "din" ile karşıllklı etkileşim içinde olmuştur. İşte bu yüzden mitler, tarih boyunca içinden çıtığı toplumların inançsal boyutta algılayış biçimlerini yansıtan ürünler olarak kabul edilmiş, bu sebeple de milletlerin kültürleri, kökenleri ve yaşantıları hakkında gizli kalmış bilgilerin gün yüzüne çıkarılmasına yardımcı olan kaynaklardan biri olarak kabul edilmiştir.

Çalışmaya konu olarak seçilen Alevî-Bektâşîliğin birçok farklı inanç sistemi ve kültürden etkilenerek senkretik bir yapı oluşturduğu görülmüş, bu çok katmanlı yapının oluşumunda mitik unsurların etkisinin çok güçlü olduğu tespit edilmiştir.
\end{abstract}

Anahtar Kelimeler: Mit, Mitoloji, Din, Alevî-Bektâşîlik, Kutsal, Senkretik

\section{Mythological Elements About Animals In The Alevi- Bektashi Belief System}

\begin{abstract}
Mythology is defined as the products produced by the humans in order to understand and explain the universe in general. Involving imaginary elements, myths take power from their bond with the reality, have undertaken significant functions to allow the individuals attain national consciousness by forming the base for the cultural assets of the society they have arisen from. As social and cultural phenomena, myths influence the social and religious lives of the societies. Certainly owing to the fact that myths involve elements of belief and religion and they are deemed to be "sacred" and "real" in their era, they have been in interaction with another important element, "religion", in shaping the social life. Consequently, myths have been regarded as products reflecting their society's belief-related conceptions throughout the history. Therefore, they are accepted as one of the sources that help the revealing of the hidden information about the cultures, roots and lives of nations.
\end{abstract}

1 Bu çalışma "Alevî-Bektaşi İnanç Sisteminde Mitolojik Unsurların Tespiti ve Değerlendirilmesi” adlı yüksek lisans tezi esas alınarak hazırlanmıştır.

Turkish Academic Research Review - Türk Akademik Araştırmalar Dergisi 
The research subject, Alevi-Bektashism was observed to form a syncretic structure under the influence of several different belief systems and cultures. Mythical elements were found to have a significant effect in the formation of this multi-layered structure. Syncretic

Keywords: Myth, Mythology, Religion, Alevi-Bektashism, Sacred,

\section{Giriş}

Toplumların sosyo-kültürel yapılarının ortaya çıkmasında ve inanç sistemlerinin şekillenerek bu günkü duruma gelmesinde belirleyici bir unsur olan mitler, hem kolektif bilincin ürünleri hem de toplumların hafizasında yıllar geçmesine rağmen izi silinmeyen kutsal gerçeklikler olarak değerlendirilebilir. Mitlerin içeriğinin kutsal bir mahiyet taşıması, onun toplumların inanç sistemlerinde kapalı kalmış katmanların gün yüzüne çıkarılması hususunda başvurulan kaynaklardan biri olmasını sağlamıștır. Mitoloji kavramı birçok inanç sisteminde olduğu gibi Alevî-Bektâşî inanç sisteminde de geniş yer tuttuğu görülmektedir. Zengin bir kültür birikimine sahip olan Alevî-Bektâşî inancı, İslâm dini içerisinde, Türk-İslam Tasavvuf geleneğine ve Eski Türk kültürünün özelliklerine göre şekillenmiş olup, geçmişte dinî, siyasî ve toplumsal baskılardan ötürü dini ritüel ve etkinliklerini kapalı cemaat yapısını altında devam ettirmiştir. Bugün ise şehirleşme ve modernleşmenin getirmiş olduğu imkânlar Alevî-Bektâşî geleneksel toplum yapısındaki dinamiklerinin değişimine neden olmuş ve kapalı toplum özelliğinden açık toplum hüviyetine kavuşmasına imkân sağlamıştır (Uçar, 2012: 75).

Kaynağını İslam öncesi inanç motif ve geleneklerinden alan Alevî-Bektâşî geleneği içerisindeki mitik unsurlar sahip olduğu bu kültürel birikimi İslam anlayışına göre şekillendirmeyi başarmış, varlığını günlük hayattan dini yaşama kadar birçok sahada hissettirmiştir. Adı geçen bu mitik unsurların farklı birçok inançtan ve kültürden etkilenerek çok katmanlı bir yapı oluşturması, bu yapının kendine özgü mitolojisinin inşasına zemin hazırlamışıtır. Bu çerçevede araştırmanın konusu Alevî-Bektâşî inanç sistemi içerisindeki mitik unsurların tespit edilmesi ve tespit edilen bu mitik unsurların bu inanç sisteminin dini ve sosyal yaşama olan yansımalarının değerlendirilmesidir.

Türk toplumunun dini, siyasi, kültür hayatında ayrı bir yere ve öneme sahip olan Alevî-Bektâşî kimliğinin farklı inanç ve görüşleri bünyesinde barındıran senkretik (bağdaştırıcı) yapıya sahip olduğu söylenebilir. Onun bu karakteristik özelliğinin ortaya çımasında önemli bir etken olarak düşünülen mitik unsurların inançsal ve sosyolojik boyutta oynadığı rolün çoğunlukla göz ardı edildiği düşünülmektedir.

\section{Araştırmanın Amacı ve Önemi}

İnsanın yaşamını anlama ve anlamlandırma sürecinde ortaya çıkan dinler, tarih boyunca kendisinden vazgeçilemeyen bir unsur olarak toplum hayatında varlığını daima korumuştur. Din, insan yaşamına anlam katarken, mitler bu anlamlandırma sürecine toplumların kolektif bilincinde sembolik bir şekle bürünerek, kültürel değerler olarak nesiller boyunca varlıklarını devam ettirmişlerdir. Bütün inanç sistemlerinde olduğu gibi Alevî-Bektâşîlik de çok katmanlı yapısından dolayı mitik ağlarla örülü bir inanç sistemidir. Alevî-Bektâşî inancı bünyesinde farklı kültür ve inanç sisteminden birçok mitik unsuru barındırdığı için tarih boyunca farklı şekillerde algılanmasına ve değişik isimlerle anılmasına sebebiyet vermiştir. Şüphesiz bu farklı yaklaşımlar ve adlandırmalar görünürde çelişkiler yumağı olarak görülse de aslında söz konusu çeşitlilik bu inanç sisteminin senkretik yapısını gösteren açık bir kanıt olarak değerlendirilebilir. Bu

Turkish Academic Research Review - Türk Akademik Araştırmalar Dergisi 
açıklamalar çerçevesinde çalışmanın amacı Alevî-Bektâşîlik inanç sisteminin zengin mitik yapısının içerisinde hayvanlarla ilgili olanlarını ortaya koyarak, söz konusu mitik unsurların tarihi arka planını tespit edip mensuplarının inanç, ibadet ve sosyal hayat ile ilgili tutum ve davranışlarına olan yansımalarını ortaya koymaktır.

Yaşadığı dönemin gerçeklik algısını yansıtan, evrenin ve insanın varoluşu konusunda içinden çıktığı toplumlarının kültürel kimlik olgusu olarak kabul edilen mitler, toplumların inanç sisteminde daima imtiyazlı bir konuma sahip olmuşlardır. $\mathrm{Bu}$ imtiyazın oluşmasının altında mitlerin kutsal ile olan ilişkisi yatmaktadır. Mitoloji ona yüklenen anlamlar sayesinde toplumların geçmişi ile geleceğini birbirine bağlayan ortak değerler ve duygulara bir gönderme yapar. İçinde kutsala ait değerleri barındırmasından ötürü mitolojilerde önemli şahsiyetlerin üstlendiği temel model roller ve bu mitosların içinde geçen tarihi olaylar toplumlardaki geleneksel değerlerin insanların zihinlerinde şekillenmesinde ve nesiller boyunca günümüze ulaşmasında önemli bir görevi üstlenmişlerdir.

Ülkemizde özellikle 1990'l1 yıllardan itibaren Alevî-Bektâşîlik ile ilgili araştırmaların sayısında gözle görülür bir artış olmasına rağmen bu inanç sisteminin mitik unsurların tespitine yönelik çalışmaların genellikle halk edebiyatı ve tarih alanlarında yapıldığı görülmektedir. Türkiye'de din sosyolojisi çalışmaları içerisinde ise Alevî-Bektaşî inanç sistemiyle ilgili birçok araştırma yapılmasına rağmen bu inanç sisteminin mitolojik yönüne ilişkin çalışmaların yeterli düzeyde olmadığı hasıl olmuştur. Buradan hareketle gerçekleştirilmesi amaçlanan bu çalışma Türkiye'de Din Sosyolojisi alanında bu konudaki eksiklikleri belli bir noktada da olsa gidermeyi hedeflediğinden önem arz ettiği düşünülmektedir.

\section{Araştırmanın Yöntem ve Teknikleri}

$\mathrm{Bu}$ çalışma nitel bir araştırma olup, ilk basamak olarak konu ile ilgili literatür taraması yapılmış, metot olarak da dokümantasyon metodu uygulanmıştır. $\mathrm{Bu}$ doğrultuda mitoloji hakkında yazılmış yerli ve yabancı kaynaklar (kitap, makale, tez, ansiklopedi maddesi... vs.) üzerinden literatür taraması yapılarak konu ile ilgili bilgilere ulaşılmıştır. Bunun yanında Alevî-Bektâşi inanç sistemi ile alakalı tarihsel, kültürel, sosyolojik, dini, antropolojik ve edebi eserler de incelenmiştir. Ayrıca Alevî-Bektâşî toplumunun sözlü anlatım geleneğinde önemli bir yeri olan ulu ozanların deyişlerinde ve cem törenlerinde söylenen gülbang örneklerinde tespit edilen mitolojik unsurlardan da yararlanılmışıtır. Bunun yanı sıra bu inanç sisteminin yazılı kaynakları arasında kabul edilen Buyruk' da geçen anlatılardan da istifade edilmiştir.

\section{Alevî-Bektâşî İnanç Sisteminde Hayvanlarla İlgili Mitik Unsurlar}

İnsanoğlu tarih boyunca hayvanlarla etkileşim içinde olmuştur. Toplumsal yaşam içersinde önemli bir unsur olan hayvanlar, insanların hayatlarında sadece etinden, sütünden, gücünden istifade edilen varlıklar olmamışlar, yeri geldiğinde Tanrıya kurban edilmek, sihir ve büyü gibi dini pratiklerde de kullanılmışlardır. İnsanların çoğu zaman bu hayvanların yırtıcıllğı ve albenisinden korku ve endişeye kapıldıkları olmuş, neticede de hayvanların olağanüstü güçleri olduğuna dair zihinlerde bir takım düşünceler belirmiştir. $\mathrm{Bu}$ düşünceler zamanla evrilerek hayvanların ilahlaştırılması boyutuna kadar uzanmış, inanç bağlamında totemleştirilerek kültsel bir sembol haline getirilmiştir (Demirdağ, 2017: 13).

Bunun yanında Türk mitolojisinde başka bir surete girme diye ifade edilen "dona girme" figüründe hayvan motiflerinin sıkça kullanıldığı, aynı şekilde yaratılış (türeyiş) ve köken mitlerinde hem etken hem de edilgen manada hayvanların isimlerinin geçtiği de bilinmektedir (Seyfeli, 2003: 42-50). Totem kabul edilen ve olağanüstü özelliklerinin olduğuna inanılan hayvanların oluşturduğu mitolojik kadro Alevî-Bektâşî inanç sisteminde de kendine yer edinmiş ve birer mitik simge haline

Turkish Academic Research Review - Türk Akademik Araştırmalar Dergisi 
dönüşmüştür. Türkler'in İslamiyeti kabul etmesiyle beraber geçirdiği değişimle Alevî-Bektâşî inanç sisteminde kendine özgü inançları meydana getirmiştir (Demirdağ, 2017:13).

\section{Turna Kuşu}

Birçok kültürde kutsal sayılan kuşlardan biri olan turna kuşu Alevî-Bektâşîler arasında da sevilen ve saygı duyulan kuşlardan biri olmuştur (Demirdağ, 2017: 15). Alevi Bektaşi inancında turna kuşunun uzun ömrü ve ebediliği sembolize ettiğine inanılır (Yıldız, 2014: 318). Alevi-Bektâşiler tarafından turnaların, yaradana duyulan aşkın cazibesiyle yollara düşen canları, turna katarının da cem ayinini temsil etttiğine inanılmaktadır (Elçin, 2003: 49). Turna kuşunun havada uçarken çizdiği figürler cem törenlerindeki semahlara ilham kaynağı oluşturmuştur. Zira AlevîBektâşîler arasında Turna ile Hz Ali arasında bir bağın olduğuna inanılmaktadır (Bozkurt, 1995: 60). Alevî Türkmenleri olarak bilinen Tahtacılar arasında Hz. Ali'nin ölümsüz olduğuna dair bir inanış mevcuttur. Hz. Ali'ye mitoljik bir hüviyet kazandıran bu bu inanışa göre Hz. Ali ölmemiş, varlığını kendi sesini turna kuşuna vererek devam ettirmiştir. Bu yüzden de Tahtacılar, Turna kuşununun öldürülmesini yeryüzünde Ali’nin varlığına son vermekle eş değer gördükleri için günah kabul etmişlerdir (Selçuk, 2008: 318). Pir Sultan Abdal deyişlerinde Turna ile Hz. Ali arasındaki ilişkiyi şu şekilde açıklamıştır:

\section{Hazret-i Şah'ın avazı}

Turna derler bir kuştadır

Asası Nil denizinde

Hırkası bir derviştedir (Gölpınarlı ve Boratav, 2017:162).

Türklerin şamaninist uygulamalarında görülen turna donuna girme inanışı, İslamiyeti kabulden sonra da Alevî-Bektâşî inancında da varlığını devam ettirmiştir. Ahmet Yesevi' nin davet edildiği ilim meclislerine turna donuna girerek vardığına, Hacı Bektaş Veli ve halifelerinin de turna donuna girdiğine inanılırdı (Melikoff, 2015: 148-150). Alevî-Bektâşî deyiş ve nefeslerinde başta Hz. Ali olmak üzere birçok Alevî-Bektâşî inanç önderinin turna donuna girdiği belirtilmektedir. Bu yüzden turna kuşu halk arasında hayrın ve güzelliğin habercisi olarak kabul edilmiş ve turnaların yolu gözlenmiştir (Demirdağ, 2017: 17).

\section{Güvercin}

Alevî-Bektâşî inanç sisteminde başta Hacı Bektaşi Veli olmak üzere önde gelen inanç önderlerine mitolojik bir hüviyet kazandıran don değiştirme motifinde karşımıza çıkan kuş türlerinden biri de güvercindir. Özellikle Hacı Bektaşi Veli ismi anılınca akla ilk olarak güvercin gelmektedir. Çünkü onun naif bir hayvan olmasının yanında barış ve sukunetin timsali olması sebebiyle bir velinin mistik karakterine uygun görülmüştür (Taşğın ve Solmaz, 2012: 108).

Alevî-Bektâşîler arasında tarihi kişiliğinden çok mitolojik yönüyle öne çıkan Hacı Bektaşi Veli, daha önce bahsedildiği üzere güvercin donuna girerek Rum diyarına gelmesi iyi niyetinin göstergesi olarak düşünülebilir. Onun gelişinden hoşnutsuz olan Rum erenleri arasından Hacı Doğrul, Rum erenlerini temsilen niyetini belli etmek için doğan donuna girerek onu avlamak istemiştir; ancak güvercin donundaki Hacı Bektaşi Veli birden insan suretine geri dönmüş ve doğanı yakalamıştır. Hatasını anlayan Hacı Doğrul pişmanlığını dile getirmiştir. Hacı Bektaşi Veli, Rum ereni Doğrul'un bu hareketine karşılık şöyle yanıt verir: "Ey

Turkish Academic Research Review - Türk Akademik Araştırmalar Dergisi 
Doğrul, er erin üzerine böyle gelmez; siz bize zalim donunda geldiniz; biz ise size, mazlum donunda; eğer güvercinden daha mazlum bir yaratık bulsaydık, onun donuna girer gelirdik" (Gölpınarl, 2017: 18-19). Alevî-Bektâşî inanç sisteminde sözlü ve yazılı kültürden aktarılan kaynaklarda adı geçen ulu şahısların birden fazla hayvan donuna girme ve kimliğini gizleme motifine yer verildiği görülmektedir (Taşğın ve Solmaz, 2012: 108). Bu menkıbede geçen olayda muhatapların güvercin ve doğan ikilisi üzerinden kendi düşüncelerini sembolik olarak aktarıldığı görülmektedir. Hacı Bektaşi Veli'nin burada Horasan erenlerini temsilen güvercin donuna girerek Rum erenlerine güvercin ruhunun asilliğini göstermeyi amaçladığı düşünülmektedir. Hacı Bektaşi Veli burada hal diliyle Hacı Doğrul üzerinden Rum erenlerine nerede ve ne zaman ve kime karşı doğan olunmasını öğreterek aslında bir mesaj vermek istemektedir (Taşğın ve Solmaz, 2012: 117).

Güvercin donuna girdiği başka bir anlatıya göre Hacı Bektaşi Veli, Horasan'da Müslüman hakın mallarını yağmalayan ve Ahmet Yesevi'nin oğlu olan Kutbeddin Haydar'ı esir alan Bedahşan halkıyla savaşmaya şahin donunda gitmiş, bu toprakları aldıktan sonra yöre halkını İslam'a davet etmiş, görevi bitince de güvercin olup Horasan diyarına geri dönmüștür (Ocak, 2017: 219). Alevî-Bektâŝi inancında güvercinin Hacı Bektaş-1 Veli ile özdeşleştirildiği görülmektedir. AlevîBektâşîler arasında güvercin kutsal kabul edildiği için evde veya kafeste beslenilmesi, avlanılması hoş karşılanmamıştır (Ocak, 2017: 222).

\section{Karga}

Kargalar, genel anlamda ölümü hatılatan siyah renkleriyle, uğursuzluk getirdiğine inanılan, kalın sesleri, leş artıkları ve çaldıkları yiyeceklerle beslenmeleri sebebiyle de kötü çağrışım yapan bir kuş türü olarak bilinmektedir (Demirdăg, 2017: $13)$.

Türk mitolojisinde karga bașta olumlu anlama sahipken daha sonra olumsuz anlamlar yüklenen bir kuş olmuştur. Altay Türklerinin yaratılış mitine göre Tanrı Bay Ülgen, insan vücudunu yarattıktan sonra ona can vermek için kargaya bir emanet verir ve Kara Han'a ulaştırmasını ister. Adı geçen mitin devamında ise karga ağzında taşıdığı bu canla uçarken yerde leş görür, dayanamaz ağzını açar ve emanet çam ağaçlarının üzerine düşer. $\mathrm{O}$ günden beri çam ağaçları dört mevsim yapraklarını hiç dökmez olur (Uraz, 1992: 156).

Kargaya yüklenen bu olumsuz düşüncelerin Türklerin İslamiyet'i kabulüyle beraber Alevi-Bektaşi inanç sisteminde de kendine yer edindiği gözlenmektedir. Bir inanışa göre kargalar Hz. Ali'nin kabrini pislemişlerdir. Çok yaygın bir hikâyeye göre ise Muhammed Peygamber düşmanlarından emin olmak için bir mağaraya saklandığında, onu ilk gören o zamanlar beyaz olan karga olmuştur. Karga, Muhammed Peygamberin saklandığı yeri ele vermek için "Ğar! Ğar!" yani "Mağara Mağara" diye bağırır. Ancak onu ne dediğini anlamayan Muhammed Peygamberin düşmanları mağaraya bakmadan oradan uzaklaşırlar. Muhammed Peygamber tehlikenin ortadan kalktığını anladığı an mağaradan çıkar ve karganın kara renge dönüşmesi için Tanrı'ya beddua eder ve karganın rengi birden siyaha döner. İşte O günden sonra da karga bu hain ötüşünü tekrar etmek zorunda kalır (Sax, 2006: 64).

\section{Anka Kușu}

Alevî-Bektâşî şiirlerinde yer alan Anka sembolizminin tasavvufi özelliğe sahip olduğu görülmekte ve Tanrın'nın birliğini simgelediğine inanılmaktadır. Anka'nın tasavvufi yönünü anlatan en önemli eser Feridüddin Attâr'ın kaleme aldığ 1 Mantıku't-Tayr'dır. Bu eserde Simurg adıyla anılan Anka'nın özellikleri geniş bir şekilde anlatııı, ardında hikayeye geçilir. Hikayede kuşların Kaf dağının arkasındaki Simurg'a ulaşmak amacıyla çıktı̆̆ı yolculukta başlarından geçen serüvenler anlatmaktadır. Bu yolculuk tasavvufta yer alan makamları sembolize

Turkish Academic Research Review - Türk Akademik Araştırmalar Dergisi 
eder. Hikayenin sonunda varmak istedikleri hedefe ulaşan kuşlar onu göremezler; çünkü o Allah'tır ve alemde görülen her şey onun varlığının birer yansımasıdır (Attar, 1998:70;Demirdağ, 2017: 16).

\title{
Aslan
}

Yiğitlik ve cesaretin sembolu olan aslan Alevî-Bektâşî inancında Hz. Ali ile özdeşleşmiştir ve onun "Allah'ın Aslanı” olduğuna inanılır. Her ne kadar bu benzetme Hz. Ali'nin korkusuzluğu ve yiğitliği sebebiyle yapılsa da şüphesiz bu inanışın bir mitik temeli bulunmaktadır (Kuşca, 2014: 128). Bu inanışa delil olarak da Hz.Ali'nin Miraç olayında aslan donuna girerek Muhammed Peygamberin karşısına çıkması gösterilmektedir (Eröz, 1990: 222).

Muhammed Peygamber Mirac'a çıkarken yolda bir aslanla karşılaşır ve yüzüğünü ona verir. Miraç dönüşü Kırklar Meclisi'ne uğrayan Muhammed Peygamberin yüzüğ̈̈ Hz. Ali tarafından kendisine verilir. Böylece aslanın gerçekte Hz. Ali olduğu anlaş1ır (Melikoff, 1999: 281). Bu durumu Pir Sultan Abdal kendi mısralarında şu şekilde açıklamıştır:

\author{
Benim aslım Horasan'dan Hoy'dandır \\ Kırklar olduğun Kanber de yandadır \\ Tanrı'nın Arslanı Ali nurdandır \\ Kırklar'a ser-çesmesin pirim Ali \\ Cümlemizden ulusun Kızıl deli \\ Kırklar Urum'a geçti sen duydun mu? \\ Tanrı'nın Arslanı geldi bildin mi (Korkmaz, 1996: 76).
}

Alevî-Bektâşîlik’te cem törenlerine girilirken dar denilen yerde peymançeye durulması Muhammed Peygamberin aslanı (Hz. Ali’yi) görünce yaptığı duruşu, meydanda bulunan postun da aslanı simgelediğine inanılmaktadır (Noyan, 2010: 27). Alevî-Bektâşî inanç sisteminde Hz. Ali ile özdeşleşen aslan anlayışının temellerini Eski Türklerdeki Şamanizm anlayışından kaynaklandığı düşünülmektedir. Türk mitolojisinde Aslanın yelesi ve postu cesaretin simgesidir. $\mathrm{Bu}$ sebeple de Türklerde savaş̧̧ı erler arasında uzun saçın yaygın olması ile aslan yelesinin yiğitlik anlamı arasında sembolik bir ilişki bulunduğuna inanılmaktadır (Çoruhlu, 2002: 136). Aslanların ve kaplanların şamanların gökyüzü ve yeraltına yaptığı seyahatlerinde onlara yardım ettiğine inanılmaktadır. Tıpkı Hz. Ali’nin aslan donuna girerek Muhammed Peygamberin Miraç yolculuğunda yolunu açması gibi (Kuşca, 2014: 129).

Türklerin İslâmiyeti kabulünden önce cesaretin, zaferin, yiğitlik ve liderliğin sembolü sayılan aslan, bu özelliğini İslâm dairesi içine girdikten sonra da devam ettirmiştir. Bu durumun bir sonucu olarak Alevî-Bektâşî geleneğinde adı önce Haydar "Aslan" olan Ali ibn Ebu Talib, ilk günlerden başlayarak "Allah'ın aslanı" olarak övülmüştür. Bu nedenle de Araplar arasında Gazanfer, "aslan", Esedullah, "Allah'ın aslanı" olarak, Fars diyarında ise Ali-şir, "Ali Aslan" olarak anılmıştır. Türklerin hüküm sürdüğü bölgelerde ise Aslan Ali ve Ali Aslan gibi sayısız isimle anılır olmuştur (Schimmel, 2004: 48).

Alevî-Bektâşîler kendi inanç sistemlerimde Aslan figürünü Hz. Ali ile o kadar özdeşleştirmişlerdir ki bu mitolojik tasavvur sadece inançsal boyutta değil sanatsal ve kültürel alanda da kendini hissettirmiştir. Alevî-Bektâşî resim

Turkish Academic Research Review - Türk Akademik Araştırmalar Dergisi 
geleneğinde aslan motifi Hz. Ali'nin bir sembolü, hatta onun vücut bulmuş hali olarak da tasavvur edilmektedir. Bu nedenle Alevî-Bektâşî yazı resimlerinde aslan başlı başına tasvir edilmiş bir hayvandır ve bu yazı resimlerde aslanın vücuduna $\mathrm{Hz}$. Ali'nin Allah'ın aslanı olmasıyla ilgili yazılmış yazılar mevcuttur (Harman, 2014: 108).

Hacı Bektaş-1 Velî’yi tasvir eden heykel ve portlerin genelinde bir kolunda aslan, diğer kolunda da geyik motifinin yer aldığı gözükmektedir. Burada yaratılış gereği birbirinin zıddı ve düşmanı olan iki hayvanın barış içinde kardeşce bir araya gelebileceğini göstererek insanlara sevgi, hoşgörü ve barışın içinde yaşanabileceği mesaji verilmektedir (Günşen, 2007: 348).

\section{Geyik}

Alevî-Bektâşîlerce kutsal kabul edilen hayvanlardan biri de geyiktir. AlevîBektâşî geleneğinde don değiştirme inancında geyik motifi mitolojik bir hüviyette karşımıza çıkmaktadır. Geleneksel Türk uygulamalarında Şamanların elbiseleri ve kullandıkları davulların üzerinde geyik motiflerine rastlanılması ve kurban ritüellerinde geyiğin tercih edilmesi onun kutsal bir hayvan olduğunun göstergesidir (Çoruhlu, 2002: 142-143).

Geyik, Türk mitolojinde genellikle kahramanların zor durumda kaldıkları durumlarda onlara kılavuzluk ederek yardımına koşan iyi ruhlu bir hayvan olarak karşımıza çıkmaktadır. Geyiğe atfedilen bu mitolojik özelliğin Türklerin, İslamiyet öncesi etkileşim içinde oldukları Budizm inancından geçtiği düşünülmektedir (Ocak, 2017: 212). Budizmdeki Buda-geyik ilişkisi Türklerin İslamiyet'i kabulüyle beraber yeni bir şekle bürünerek Evliya-geyik formunda karşımıza çıktığı söylenebilir. Alevî-Bektâşî menâkıbnâmelerinde geyik, evliyaların don değiştirmek motifinde kullandığı hayvanlardan biri olmuştur. Bu mitolojik anlatıların genel özelliği geyik donuna giren evliyaların kendisini avlamak isteyen avcılara yol göstererek doğru yolu bulmalarına yardımcı olmalarıdır (Güngör ve Aksoy, 2012: 254).

$\mathrm{Bu}$ anlatıların içeresinde en güzel örnek Kaygusuz Abdal Menâkıbnâmesi'ndedir. Adı geçen Menâkıbnâmeneye göre Alanya Beyi'nin oğlu Gaybî Bey (henüz Kaygusuz Abdal lakabını almamıştır) bir gün ava çıkar. Av sırasında bir geyik görür ve okuyla koltuk altından yaraladığ 1 geyiğin peşine düşer. Gaybî Bey'in yaraladığı geyik kaçmaya başlar. Geyiği takip eden Gaybî Bey, Abdal Musa'nın dergâhının önüne geldiğinde geyik birden ortadan kaybolur ve dergâha girerek, yaraladığı avını ister. Bunun üzerine dergâhta bulunan Abdal Musa'nın müridleri böyle bir geyik görmediklerini Gaybî Bey'e söylerler. Dervişler ile Gaybî Bey arasında geçen bu konuşmayı işiten Abdal Musa, dervişlerinden Gaybî Bey'i yanına çağırmalarını ister. Bunun üzerine Gaybî Bey Abdal Musa'nın yanına gider. Gaybî Bey, avını okla vurduğunu, onu buraya kadar takip ettiğini, avının burada olduğunu Abdal Musa'ya da söyler. Bunun üzerine Abdal Musa Gaybî Bey'e "attığın okunu görünce tanıyabilecek misin?" diye sorar. Gaybî Bey'in de okunu tanıyacağını söylemesi üzerine Abdal Musa kolunu kaldırır ve Gaybî Bey'in geyiğe attığı okun Abdal Musa'nın kolunun altındaki okla aynı olduğunu anlar. Bunun üzerine Gaybî Bey, pişman olur, Abdal Musa'dan özür diler. Kendisine intisap ederek müridi olmak istediğini belirtir. Kaygusuz Abdal'ın babası oğlunun dergâha gidip de böyle bir dervişin müridi olmasını gururuna yediremez. Hemen Abdal Musa'nın yaşadığı yörede sözü geçen Teke Beyi'nin yanına giderek oğlunu kurtarmasını ister. Teke Beyi adamlarından birini gönderip Abdal Musa'yı huzuruna getirmesine ister; fakat şeyhin kerametiyle atından inerken ayağı üzengiye takılır, atının ürkmesi sonucu sürüklenerek paramparça olur. Bu duruma öfkelenen Teke Beyi emrindeki askeri birlikleri Abdal Musa'yı yakalamak için gönderir ve onu yakmak için büyük bir ateş hazırlatır. Durumundan haberdar olan Abdal Musa, müritleri ile beraber sema ederek Teke Beyi’nin üzerine yürür, taşlar ve ağaçlar da

Turkish Academic Research Review - Türk Akademik Araştırmalar Dergisi 
ona eşlik eder. Böylece yanan ateşin yanına gelirler ve sema ederek yanan ateşin içine girerler ve ateşi söndürürler. Sonra tekkeye geri dönerken dağdan kara bir canavar iner. Abdal Musa bunun Teke Beyi’nin ruhu olduğunu söyler. Oradaki dervişlerden biri canavarı öldürür. Bu sırada Teke Beyi’nin kendisi de ölmüştür. Bunun üzerine Kaygusuz'un Babası, Abdal Musa'nın Hak erenlerinden biri olduğunu anlar, Abdal Musa'nın elini öper ve oğlunun burada hizmet etmesine müsaade eder. Gaybi, burada kırk y1l boyunca hizmet eder, şeyhi ona Kaygusuz lakabını verir ve bundan sonra halk arasında Kaygusuz Abdal ismiyle anılır olur (Güzel, 1999: 20-28; Atalay, 2015: 86-89).

Bu menkıbede Abdal Musa'nın geyik donuna girerek Kaygusuz Abdal'1 ardından sürüklemesi ve dergâhın kapısına kadar takip ettirmesi geyiğin insanlara yol gösterici işlevini göstermesi bakımından önem arz ettiği düşünülmektedir. Diğer taraftan Teke Beyi'nin ruhunun canavara dönüşmesi, o ölünce beyin de ölmesi ve aynı şekilde dağların ve taşlarının sema ayinine eşlik etmesi Türklerin İslamiyet öncesi inanç sistemlerinde mevcut olan bazı benzer mitik motiflerdir (Tekin, 2011: 271). Altay ve Yakut Türklerindeki şaman inancında her şamanın kendine özgü bir ruhu olduğu ve bu ruhun bir hayvanda görünür kılındığı inancı mevcuttur. Şamanın hayatı bu hayvan şekline bürünen ruhların varlığına bağlıdır. Hatta Yakut Türklerinde bu inancın çok gerilere doğru gittiğini, herkesin bir hayvan donuna girebildiği inanılmaktadır (Ocak, 2017: 225). Aynı şekilde ağaçların ve taşlarının sema ayinine eşlik etmesi Türklerin İslamiyet öncesi etkileşim içinde olduğu tabiat kültüyle alakalı olduğu düşünülmektedir. Bu tespit edilen mitik motifler bize Şaman unsurlarının Alevî-Bektâşî inanç sistemi içinde varlığını devam ettirdiğini ve bu inanç sisteminin kendine özgü bir mitoloji örgüsünü oluştururken farklı inanç sistemlerinden etkilendiğini göstermesi bakımından önemli olduğunu düşündürmektedir.

Alevî-Bektâşî inancında geyik-evliya ilişkisine örnek gösterebilecek başka bir tarihi şahsiyet de Geyikli Baba'dır. Geyikli Baba'nın Bektâşî tarikatıyla özdeşleşmesi Abdal Musa ile olan yakın ilişkisinden kaynaklandığı düşünülmektedir (Uçar, 2012: 81). Geyikli Baba'nın Alevî-Bektâşîler arasında mitolojik yönüyle ön plana çıkmasını sağlayan olay adından da anlaşılacağı üzere vaktinin büyük bir kısmını geyiklerle geçirmesindendir. Yaşadığı dönemde geyikleri evcilleştirerek binek hayvanı olarak kullandığı bilinen Geyikli Baba, zaman zaman geyiklerden yük hayvanı olarak da faydalanmış ve onların sütünden yararlanmıştır. Geyikli Baba'nın geyiklerle olan bu münasebeti o kadar kuvvetlidir ki bazen geyik şekline girip dolaştığı anlatılmaktır (Su, 2011: 161-162 ; Ocak, 2017: 215).

Hacı Bektaş-1 Veli'yi tasvir eden heykel ve portrelerde O’nun kucağında yer alan geyiğin, sulak bölgelerde yaşayıp pisliğin olduğu yerden atlayarak geçtiği ve mecazi anlamda da kötülüklere bulaşmadığı için günahlardan arınmanın ve masumiyetin sembolu olarak kabul edilmiştir (Günşen, 2007: 348).

Alevî-Bektâşî inancında ulu kişilerin geyik donuna girdiği inancı onun kutsal bir hayvan olarak kabul görmesini sağlamış, bu anlayışın neticesinde de AlevîBektâşîler arasında geyiğin avlanması hoş karşılanmamıştır. Bütün Tahtacı ve Yörük aşiretleri arasında yaygın olan inanışa göre geyik vuran avcıların başlarına mutlaka bir felaket geleceği anlayışı mevcuttur ve halk arasında bu konuda da sayısız rivayetler anlatılmaktadır (Güngör ve Aksoy, 2012: 254 ; Selcuk, 2008: 319). Ayrıca geyik boynuzunun kötülüklerden ve tehlikelerden koruyucu özelliği olduğuna inanılmakta ve birçok Alevî-Bektâşî türbesinde titizlikle muhafaza edilmektedir (Y1ld1z, 2014: 318).

\section{Tavşan}

Alevî-Bektâşîler arasında tavşan farklı algılamalardan ötürü daha çok olumsuz bir hayvan olarak karşımıza çıkmaktadır. Anadolu Alevîliğinin bağlı

Turkish Academic Research Review - Türk Akademik Araştırmalar Dergisi 
olduğu İslamın temel kaynaklarında tavşan etinin yenilmesi ile ilgili herhangi bir yasak bulunmamaktadır. Alevî-Bektâş̧lerin bu yasağı birçok sebebe dayandırdıkları gözlenmektedir. Bu çerçevede farklı söylentilerin bulunduğu ve bununla ilgili çeşitli gerekçelerin ileri sürüldügü gözükmektedir. Bu gerekçeler içinde en çok dikkat çekenler, tavşanın fizyolojik yapısıyla ilgili olanlardır (Yıldız, 2014: 316-317). Bunlardan bazıları şu şekildedir:

İslam dininde geviş getirmeyen ve çift tırnaklı olmayan bütün hayvanlar dinen necis olarak kabul edilmiş̧ir. Tavşan geviş getirmeyip, çok tırnaklı olduğu gibi hayız görme özelliğine de sahiptir. Bu nedenle Alevîler tarafindan necis olarak kabul edilmiş ve yenmesi yasaklanmıştır (Aslanoğlu 1999a: 125 ; Roux, 1997: 67).

Tavşanın başı kediye, kulakları eşeğe, burnu fareye ve ayakları köpeğe benzetildiği ve tavşanın etinin kan pıhtısından oluştuğu ve pişirilince etinin suda kayboduğu inancından ötürü yenilmesi doğru görülmemektedir (Er, 2014: 203-204 ; Aslanoğlu, 1999b: 106 ; Roux , 1997: 67 ; Yıldız, 2014: 317).

Alevî-Bektâşîler arasında tavşan etinin yenmemesinin ve sevilmemesinin altında birtakım inanışların kökenlerinin $\mathrm{Hz}$. Ali ile ilintili olduğu düşünülmektedir. Bunlardan bazıları şu şekildedir: Hz. Ali'nin atı Düldül'ün bir tavşan tarafından ürkütülmüş olduğu ve tavşanın $\mathrm{Hz}$. Ali'nin beslediği kedisine benzediği inancıdır (Roux, 1997: 67; Er, 2014: 203-204).

Alevî-Bektâşîler arasında tavşan etinin yenmemesi ve yasak olmasının sebeblerininden biri de onunla ilgili bazı mitolojik anlatılardır. $\mathrm{Bu}$ anlatılardan bazıları şunlardır:

Bunlardan biri Hazreti Hüseyin'i şehit eden Yezid'in ve Hz. Ali'nin düşmanı olan Muaviye'nin kıyamet gününde tavşan şeklinde haşrolacağının kabül edilmesidir (Kotle, 2010: 24-27). Bir diğeri ise Yezid ve Muaviye'nin ruhunun bu dünyada tavşan donuna büründüğü inancıdır (Roux, 1997: 67 ; Er, 2014: 204; Yıldız, 2014: $317)$.

Alevî-Bektâşîler arasında tavşan etinin yenmemesi ile ilgili olarak öne sürülen bir diğer mitolojik kökenli gerekçenin Hızır inancıyla alakalı olduğu düşünülmektedir. İnanışa göre, Hızır Nebi dara düşen, kendisinden yardım isteyen kimselere farklı şekillerde yaklaşmaktadır. Hızır'ın yardım etmek amacıyla suretine büründüğü hayvanlardan birisinin de tavşan olduğuna inanıldığı için tavşanı öldürmek ve etini yemek doğru kabul edilmemektedir (Ergun, 2011: 287).

$\mathrm{Bu}$ açıklamalardan tavşanın Alevî-Bektâşîler arasında kötü bir imaja sahip olduğu anlaşılmakadır. Konuyla ilgili yapılan araştırmalarda, yaygın görüş olan tavşanın hayız görmesi inancının gerçekte bilimsel bir temelinin olmadığı ortaya çıkmıştır. Tavşanın dişiliğinin ön plana çıkarıldığı bu inancın mitolojik kökenli olduğu anlaşılmaktadır. Alevî-Bektâş̂ler arasında tavşanın don değiştirme motifinde kullanılmasının tavşan hakkında hem olumlu hem olumsuz çıkarımlar yapılmasına sebebiyet verdiği anlaşılmaktadır (Ergun, 2011: 287). Daha önce de bahsedilen Hz. Hüseyin'in katili olan Yezid ile Hz. Ali'nin düşmanı olan Muaviye'nin kıyamet gününde tavşan donuna gireceği inancı neticesinde Alevî-Bektâş̂llerin tavşanı, kötülüğün sembolü olarak kabul edilen bu iki kişiyle özdeşleştirdikleri gözükmektedir (Er, 2014: 204). Bununla birlikte tavşanın, Hz. Ali'nin kedisine benzetilmesi ve Hızır Nebi'nin tavşan donunda görünmesi onun bazen koruyucu ve yol gösterici bazen de kutsala yaklaşmada aracı olan bir simge olarak karşımıza çıktığını göstermektedir (Selçuk, 2008: 326). Şüphesiz bu durumun mitolojik kökenli kutlu iyelerin tavşan suretine girmesi ile alakalı olduğu düşünülmektedir. Gerek Alevî-Sünni gerekse mitolojik geçmişle bugün arasında birbirinin tamamen zıddı gibi görünen bu algı farklılı̆̆ının sebebi şu şekilde açıklanabilir: Bir inanç yeni bir inançla karşılaştığında bazen değerler arasında çatışma yaşanır. Bazen uzun yıllar

Turkish Academic Research Review - Türk Akademik Araştırmalar Dergisi 
süren bu çatışma sırasında bazı değer yargıları dönüşüm geçirerek tanınmaz hale gelebilir, bazıları da zıt anlam kazanarak yaşamanı sürdürebilir. Türkler, tarih boyunca geniş bir coğrafyada hüküm sürmüş, farklı din ve inanç gruplarıyla etkileşim içine girdiğinden kendi inanç katmanları arasında farklı algılar meydana gelmiştir. Türklerin inanç sisteminde meydana gelen bu farklı algılamalar göçler vasıtasıyla varlığını Anadolu coğrafyasında da hissettirmiş, Alevî-Bektâş̂i inanç sisteminin oluşmasında önemli katkılar sunmuştur. Eliade inanç sistemlerindeki bu farklı algılamaları "kutsalın çelişkiliği" olarak tarif etmiş ve kutsalın/ tabunun hem "kutsal" hem de "kirli" ya da "lanetli" anlamlarını içinde barındırdığına dikkat çekmiştir. Eliade'a göre tabu olan nesneler morfolojik bakımdan zenginlik arz etmektedir. Bu morfolojik zenginlik tavşanda da bulunmaktadır. Zira yukarıda da belirtildiği gibi Alevî-Bektâşîler tavşanın başı kediye, kulakları eşeğe, burnunun fareye ve ayakları köpeğe benzediğini iddia etmektedirler. Kutsalın çelişkiliğine Eröz de vurgu yapmış, tavşanın eski bir Türk tözü olması sebebiyle, totemde sevilen ve saygı duyulan yönlere karşılık, nefret edilen taraflarının da bulunduğunu belirtmiş ve zamanla kötü tarafının daha üstün geldiğini ifade etmiştir. Eröz'e göre, Alevî-Bektâşî topluluklarının tavşan eti yememeleri ve avlamamaları, tavşanın bir totem (ongun-töz) olarak kabul edilmesinden ötürüdür (Eröz, 1977: 402; Ergun, 2011: 287-288).

\section{Yılan}

Yılan, tarih boyunca tüm medeniyetlerin mitolojilerinde farklı sembolik anlamlar ifade eden bir hayvan olarak karşımıza çıkmaktadır (Boztemir, 2103: 114). Alevî-Bektâşî topluluğunun hüküm sürdüğü Anadolu coğrafyasında yılan, tıpk1 tavşan örneğinde olduğu gibi hem kendisinden korkulan hem de kendisine sayg1 duyulan bir hayvan olarak görülmüştür (Ölmez, 2010: 5).

Dünya mitolojilerinde evrensel bir motif olarak karşımıza çıkan yılan figürünün Türk mitolojisinde hem olumlu hem de olumsuz sembolleri barındırdığı gözükmektedir. Olumlu manada şamanlara yer altı ve gökyüzüne yaptıkları yolculuklarda yardımcı olan hayvan ruhlardan biri olarak kabul edilmektedir (Seyidoğlu, 2002: 87). Türklerin halk inanışlarında "ev iyesi”" olarak kabul edilen yılan, yaşadığı evin bereketi olarak kabul edilmektedir. Bu yüzden de öldürülemez, eğer öldürülürse evin bereketinin kaçacağına inanılmaktadır (Beydilli, 2015: 616). Olumsuz manada ise Alevî-Bektâşîler arasında tespit edilen tenasüh inancı gereği ikinci defa dünyaya gelişte kötü insanların şekline büründüğü bir hayvan olarak karşımıza çıkmaktadır (Ölmez, 2010: 5).

Alevî-Bektâşî menâkıbnâmelerinde ise yılan genellikle insanın kötü yönleriyle özdeşleşen mitolojik bir figür olarak karşımıza çıkmaktadır. Bunun en güzel örneklerinden birisi Hacı Bektaşi Veli ile Seyit Mahmut Hayrani arasında geçen şu anlatıdır:

Hacı Bektaş-1 Veli’nin ünü ülkenin dört bir yanına yayılmıştır. Her yerden erenler, onu görüp ziyaret etmek istemektedir. Akşehir'de ikamet eden Seyyid Mahmud Hayrani adlı bir eren vardır. Bir gün bu er; bir aslana biner, bir yılanı da kamçı yapıp üç yüz Mevlevi dervişi ile Hünkârı görmek için yola çıkar. "Aliler sırtına yaklaştı" denilerek Hünkâr'ın kendisine haber verilir. Hünkâr, "O gelen kimse, canlıya binmiş, gelmiş; biz de cansıza binip karşılayalım” der. Hünkâr, “Kızılca Halvet” yakınındaki bir kızıl kayaya binip, kayaya kendini Allah’ın izniyle o gelen erenlerin yanına götürmesini söyler. Kaya, hemen kuş uçar gibi gürleyip Aliler sırtına doğru yönelmeye başlar. O kayanın başının şimdiki şekli tıpkı bir kuşa benzemektedir. Seyyid Mahmud Hayrani, hünkârı cansız bir kaya üzerinde kendilerine doğru gelirken görünce hatasını anlar ve "küstahlık edip haddimizi aşmısız" deyip hemen bindiği aslanın üzerinden inip elindeki kamçı niyetine tuttuğu yılanı da atarak teslimiyetini gösterir. Hünkâr kayaya "dur!” der ve o kaya durur. O

Turkish Academic Research Review - Türk Akademik Araştırmalar Dergisi 
Tekke kayanın dibine oturup tam bir hafta hep birlikte yiyip içip sohbet ederler. Sema'ı safa ederler. Daha sonra Hünkâr, kendisinden ayrılmak için izin isteyen Hayrani’ye izin verir. O da erenler ile vedalaşıp Akşehir'e doğru yürür (Danık, 2006: 47-48).

Birbirine üstünlük sağlama diye de adlandırabileceğimiz bu keramet gösterme yarışmasında aslan ve yılanın mitolojik özellikleri karşımıza çıkmaktadır. Seyit Mahmut Hayrani'nin aslanın sırtına binmesi onun kendi nefsine sağladığı üstünlüğü, elindeki yılanı kamçı gibi kullanması ise nefsinin kötü yönlerini terbiye ettiğini sembolize etmektedir (Dağtaşoğlu, 2014: 159). Bu karşılaşma sahnesi, Hacı Bektaş-1 Veli'nin rakibi olan Seyyid Mahmut Hayrani'nin gölgesinde kalmayarak saygınlık ve üstünlüğünü göstermesi bakımından prestij mitoslarına örnek olarak da gösterebilir (Danık, 2006:50).

Hacı Bektaş-i Veli'nin kendisinin daha üst makamda olduğunu gösterme amacıyla kayayı yürütmesi, geleneksel Türk dini içerisinde var olan Kaya ve Taş kültüyle alakalı olduğu düşünülmektedir. Türkler, İslamiyet öncesi devirlerde bazı taş ve kayaları kutsallaştırarak içlerinde birtakım ruhların ve ilahların olduğuna inanmış, bu sebepten ötürü de zaman zaman bu taş ve kayaları takdis edip onlara hürmet göstermişlerdir. Türklerin bu anlayışı İslamiyet sonrası dönemde de devam ettirdiği görülmektedir. Bunun en güzel örneklerden biri de Hünkar'ın türbesine yaklaşı $350 \mathrm{~m}$. mesafede bulunan ve Hacı Bektaş-1 Veli'nin keramet göstererek yürüttüğüne inanılan kayadır. Alevî-Bektâşîlerce kutsal kabul edilen bu kayanın içindeki oyukta Bektâşî dervişlerin eskiden kırk gün boyunca inzivaya çekildiği anlatılmaktadır. Bugün Alevî-Bektâşîlerce ziyaret mekânı olarak kabul edilen kayalar ve taşların, bazı yörelerde bu kadar hürmet ve saygı görmesinin bir başka sebebi de Alevî-Bektâşî topluluğu arasında eskiden beri var olan bu kültün Hacı Bektaşi Veli'nin mitolojik şahsiyetine izafe edilmesi olarak düşünülebilir (Ocak, 2017: 122-124; Tanyu, 1987:163-164).

\section{Kaz}

Türkmen Alevî topluluğu olarak bilinen Tahtacılar arasında kaz çok sevilen bir hayvandır. Kaza karşı duyulan bu sevginin kaynağının dini temelli olduğu düşünülmektedir. Onlara göre kaz, Hz. Ali’nin öldürüleceğini önceden hisseden bir hayvandır. Tahtacılar, Hz. Ali’nin camide öldürüldüğü gün kazların bunu önceden hissettiğine bu yüzden de Hz. Ali'nin gitmesine mani olmak için gagalarıyla onun elbisesini çektiğine inanmaktadırlar (Selçuk, 2008: 317). Tahtacı topluluğunun kaza karşı duyduğu bu saygının şiirlere de yansıdığı da görülmektedir (Belli ve Belli, 2012: 115-116).

\section{Tehlikeyi sezerler}

Bol bol suda yüzerler

Kazın kutsallığını

Hz. Ali Söyler

O gün yüzmüşleriydi

Derde düzmüşleriydi

Ali’nin öleceği

Günü sezmişleriydi (Yahya Azeroğlu) 
Mersin ili Çaylak Oymağı'na bağlı Tahtacı topluluğu arasında kaz ayağına benzer bir sembolün kendilerine mahsus bir işaret olduğu inancı mevcuttur. Bununla birlikte yapılan araştırmalarda Tahtacı topluluğunun bu işaretin neyi simgelediği hususunda yeterli bilgiye sahip olmadığı ortaya çıkmıştır. $\mathrm{Bu}$ işaretinin mezar taşlarına kazındığı ve iş gömlekleri ve gelinliklerin üç eteklerinde motif olarak işlendiği tespit edilmiştir (Cıblak, 2003: 236).

\section{Horoz}

Alevî-Bektâşîlik'te horozun ayrı bir önemi vardır. Horozun diğer bir adı da Melek Cebrail'dir. Alevî-Bektâşîlere göre Kura'ın ilk emri olan "Oku” ayeti indiğinde Melek Cebrail Muhammed Peygambere horoz şeklinde görünmüştür. İşte bu yüzden cem törenlerinde kurbandan önce Cebrail (horoz) kesilmektedir (Tekin, 2011: 364). Cebrail kurbanı adı altında kesilen horozunun en belirgin özelliği tüylerinin beyaz renkli olmasıdır. Tahtacılar arasında Allah'ın sabahın yaklaştığını hayvanlar arasında sadece horoza bildirdiğine inanılmaktadır (Selçuk, 2008: 318319). Pir Sultan Abdal kendi dizelerinde arştaki horozdan şu şekilde bahseder:

Evliyalar enbiyalar varisi
Kalkar hacet diler gece yarısı
Çağrışır, ötüşür arşın horuzu
Doğdu hacet vakti, kalk hacet dile (Gölpınarlı ve Boratov, 2017:231).

Arı

Çalışkanlığı ile özdeşleşen arı, sadece kendine has bir ürün olan bal ile insan sağlığı için pek çok hastalıklara şifa kaynağı olmuş, bu özelliği sayesinde birçok mitolojide kutsal bir hüviyete sahip bir hayvan olarak karşımıza çıkmıştır (Boztemir, 2013: 96). Anadolu Alevîliği üzerinde etkili olan Safevilerin mensubu olduğu on iki imam Şiiliği inancında da karşımıza çıkan arı motifi Alevî-Bektâşîlerce de Hz. Ali ile özdeşleştirilmiştir. Allah'ın aslanı olan Hz. Ali aynı zamanda arıların da şahı olarak kabul edilmiştir. Gerçek müminler de bal yapan arılara benzetilmiştir (Alkan, 2005: 107).

Bir rivayete göre, Muhammed Peygamber balın ölüm dışında her derde çare olacağını söylemiştir. Bu da balın önemini artıran sebeplerden biri olarak kabul edilmektedir. Arı ve bal Alevî-Bektâşî şiirinde kendisinden sıłça bahsedilen unsurlardan biri olmuştur. Bazı bölümlerde sadece arı veya bal isimleri ayrı ayrı geçse de, genel olarak ikisi de birlikte anılmaktadır. Alevî-Bektâşî erenlerinin dilinde arı dervişi simgeler, bal ise dervişin elde etmeye çalıştığı kutsal gerçektir, yani Hakk'1 bulmaktır (Alkan, 2005: 107). Alevî-Bektâşî inancında arıların birlik içinde hareket etmesi, cem olmayı simgeler. Petek de bu hakikatin işlenmesi, bal ise hakikatin meyvesi olarak düşünülmüştür (Boztemir, 2013: 96). Pir Sultan Abdal'ın şu dizeleri bu görüşü destekler niteliktedir:

Halimizi hal eyledik

Yolumuzu yol eyledik

Her çiçekten bal eyledik

Arıya saydılar bizi (Gölpınarlı ve Boratav, 2017: 125).

Sonuç ve Değerlendirme

Turkish Academic Research Review - Türk Akademik Araştırmalar Dergisi 
İnsanlık tarihi kadar eski bir kurum olan mitler, içinden çıktığı toplumların kolektif bilincin teşekkülü sonucu ortaya çıan ürünlerdir. Toplumların sosyal ve dini hayatının şekillenmesinde önemli bir unsur olan mitler kutsal ile olan ilişkisinden ötürü dinlerin yetersiz kaldığ durumlarda bu boşluğu doldurma görevini üstlenmiş, bu yüzden de toplumların en gizli noktalarına ulaşma konusunda bir nevi anahtar konumunda değerlendirilmiştir. Mitler, toplumların gerçeklik algısını yansıttığı için dini ve sosyal yaşamına canlılık getirmiştir. Mitler, tarihsel süreçte farklı coğrafyalardaki değişik inanç sistemleriyle girilen etkileşim sonucunda ortaya çıkmış birer kültürel olgu olarak değerlendirilmiştir. İçinde değişik inanç unsurlarından malzemelerin bulunduğu mitler ritüeller aracılığıyla varlığını günümüze kadar ulaştırmış, kutsal törenler sayesinde canlılığını muhafaza etmeyi başarmıştır.

Dinler tarihinin en eski inanışlarında her nesnenin bir ruhu olduğu inancı, bir canlıyı veya bir nesneyi kendisi için kutsal sayma inanışını beraberinde getirmiștir. $\mathrm{Bu}$ inanış asırlar boyunca farklı dinler ve inanışların şemsiyesi altında varlığını devam ettirmiş, toplumların kolektif bilincinde farklı şekillerde kendini gösterebilme imkânı bulmuştur. Bunun bir yansıması da hayvanları kutsal görerek ve onlara tapınma şeklinde karşımıza çıkmaktadır (Armutak, 2002: 412). Alevî-Bektâşî geleneğinde önemli bir yer tutan bu zengin mitolojik kadro içerisinde bazı hayvanlara iyi, bazı hayvanlara kötü anlamlar yüklendiği görülmektedir. AlevîBektâşî inancında kutsal kabul edilen hayvanlar içerisinde en çok kullanılan hayvan figürlerinin "aslan", "turna", "güvercin" ve "geyik" olduğu görülmektedir. Şüphesiz bu figürlerin Alevî-Bektâşî inanç sisteminde karizmatik şahsiyetler olarak kabul edilen Hz. Ali, Hacı Bektaşi Veli ve Abdal Musa ile özdeşleştirmiş olmasının etkisi büyüktür. Turnanın sesinin Hz. Ali'nin sesi olduğu inancı ve gökyüzündeki çizmiş olduğu figürlerin Cem törenlerindeki semah ayinlerinde sergilenen figürlerle olan benzerliği, kutsal kabul edilmesinde etkili olduğu düşünebilir. Aynı şekilde Miraç mitinde Hz. Ali'nin aslan donuna girerek Muhammed Peygamberinin Miraç yolculuğunda karşısına çıkması ve Aslan figürünün hem kahramanlık hem de liderlik vasıflarının, Alevî-Bektâşî inancındaki Hz. Ali mitiyle benzerliği AlevîBektâşîler arasında aslan figürünün kutsal kabul edilmesine sebep olduğu düşünülebilir. Alevî-Bektâşî geleneğinde kutsal kabul edilen diğer bir hayvan da geyiktir. Geyiğin bu denli önem arz etmesinde en büyük etkenin Bektâşilîğin ikinci kurucusu kabul edilen Abdal Musa ile olan yakın ilişkisidir. Kaygusuz Abdal menâkıbnâmesinde geçen olay da geyiğin yol gösterici özelliğine vurgu yapılmıştır. Adı geçen mitolojik anlatı da geyiğin kendisini avlamak isteyen Gaybi Bey'e rehberlik ederek Abdal Musa dergâhına ulaşmasında yol gösterici özelliği vurgulanmaktadır. Hacı Bektaş-i Veli'nin portelerinde kucağında karakter olarak birbirinin zıddı olan aslan ve geyik figürlerinin aynı anda bulunması onun ismiyle özdeşleşen Alevî-Bektâşî inancındaki hoşgörü ve kardeşlik vurgusuna dikkat çektiği düşünülebilir. Ayrıca Alevî-Bektâşîlerce ulu kişiler olarak kabul edilen şahsiyetlerin mitolojik bir hüviyete bürünmesine sebebiyet veren don değiştirme kabiliyetlerini kullanırken tercih ettikleri hayvanlar Alevî-Bektaşîler arasında genellikle kutsal kabul edilmiştir.

Alevî-Bektâşî geleneğinde uğursuz olarak kabul edilen hayvanların başında tavşan gelmektedir. Şüphesiz bunda tavşanın fizyolojik özelliklerinin yanında AlevîBektâşîler arasında lanetle anılan Yezid ve Maviye isimleriyle özdeşleşmiş olması tavşanın uğursuz kabul edilmesinde önemli bir etken olarak kabul edilmektedir.

Türkler'in İslam'la tanışmadan önce etkileşim içinde bulunduğu Şaman inancında ulu kişiler olarak kabul edilen şamanların hayvanlarla etkileşime geçebildiği ve gerekli durumlarda hayvanların şekline girebildiği inancı mevcuttu. İslam'la tanıştıktan sonra da bu inanışlarını Alevî-Bektâşî inanç sisteminde de devam ettirebilmişlerdir. Aradaki tek farkın eski inanışlarında ulu kişiler olarak

Turkish Academic Research Review - Türk Akademik Araştırmalar Dergisi 
kabul edilen Şamanların yerine Alevî-Bektâşî geleneğinde erenlerin almıș olmasıdır. Bu bilgiler ışı̆̆ında diyebiliriz ki; Alevî-Bektâşî inanç sisteminde hayvanlarla ilgili tespit edilen mitik unsurlar içerisinde Türk mitolojisinin önemli bir yeri bulunmaktadır.

Birçok inanç içerisinde karşımıza çıkan mit kavramı ve onunla ilişkili olan ritüeller Alevî-Bektâşî inanç sistemi içerisinde de kendine yer bulmuştur. AlevîBektâşilik kendi temel inanç öğretilerini, inanç pratiklerini çok geniş bir kaynak yelpazesine dayandırarak oluşturmuştur. İslam dairesi içerisinde Hz. Áli ve O'nun soyundan gelen Ehl-i Beyt'e karşı duyulan sevgi çerçevesinde şekillenen AlevîBektâşî inancının temellerine inildikçe karşımıza farklı inanç sistemlerinden değişik mitolojik kökenli unsurların çıktığı görülmektedir. Türkler, ana yurdu kabul edilen Orta Asya'nın gerek coğrafi şartlarının etkisi, gerekse asırlar boyunca değişik inanç sistemlerine ev sahipliği yapması sebebiyle ortaya çıkan inanç anlayışlarını, Anadolu coğrafyasına göçler vasıtasıyla aktarmayı başarmıştır. Türkler kendi inanç sistemlerini bu coğrafyada henüz yeni filizlenen İslam inancının temel öğretilerinin uyuşan yönleriyle bağdaştırmayı başararak kendine özgü bir inanç sistemi meydana getirmiștir. İște böyle bir ortamda şekillenen Alevî-Bektâşî inanç sisteminin Şamanizm ve Tabiat kültleri başta olmak üzere Budizm, Manihezm, Zerdüştlük, Gök Tengri ve Mazdek inancı gibi İslam öncesi dinler ve hüküm sürdükleri geniş coğrafyanın mitolojik unsurlarından etkilendiği görülmektedir. $\mathrm{Bu}$ karşılıklı etkileşim öylesine güçlü olmuştur ki ortaya çıkan senkretik anlayışın bugünkü Alevî-Bektâşî inanç sisteminin özünü oluşturduğu düşünülmektedir. Bu mitolojik unsurlar İslam şemsiyesi altında şekillenerek Alevî-Bektâşî toplumunun sadece inançsal boyutuna etki etmemiş, sosyal-kültürel yaşamında da derin izler birakmıştır.

Mitlerin mahiyetinde sadece içinde yaşadığımız evrenin oluşum süreci ve gizemine ait mesajlar bulunmaz. Mitlerin aynı zamanda toplumların inanç ve sosyal yaşamında var olan öğretilerin gelecek kuşaklara aktarımında pedagojik fonksiyonu da bulunmaktadır. Bu düşünceden hareketle bu araştırmanın inceleme konusu olan Alevî-Bektâşî inancındaki temel öğretilerin geçmişten günümüze ulaşmasında mitolojik unsurların da etkisi olduğu düşünülmektedir.

Hayvanlarla ile ilgili tespit edilen mitolojik unsurlarda ise tespit edilen en önemli husus bazı hayvanlara iyi, bazılarına ise olumsuz anlamlar yüklenmesidir. Burada dikkat çeken en önemli ayrıntı Alevî-Bektâşî ulu kişilerin Tanrı vergisi bir özellik olduğuna inanılan "don değiştirme" kabiliyetlerinde kullandığı hayvan motiflerine genellikle olumlu anlamlar yüklenmesidir. Bunların içinde özellikle Hz. Ali ile "aslan", Hacı Bektaş-1 Veli ile "güvercin”, Abdal Musa ile Geyik” figürünün özdeşleştirilmesi en bariz örneklerdendir. Özellikle İslamiyet öncesi Türklerin inanç sistemlerinden biri olan Şamanizm'de Şaman din adamlarının hayvanların suretine girebileceği inancı İslam bünyesinde ortaya çıkan bu inanç sisteminde yerini AlevîBektâşî ulu erenlere bıraktığı gözükmektedir. Bu durum Alevî-Bektâşîliğin senkretik bir yapı arz ettiğini göstermekte ve bu mitik unsurlar bu yapının oluşum sürecinde önemli bir basamak olarak değerlendirilmektedir. Burada dikkat çeken başka bir husus da şudur ki; başta Hacı Bektaş Veli olmak üzeri yaşadığı dönem itibariyle önemli kabul edilen birçok Alevî-Bektâşî inanç önderinin; rakiplerinin gölgesinde kalmamak ve karşı tarafa saygınlık ve üstünlüklerini göstermek amacıyla sergiledikleri olağanüstü durumların, aynı şekilde haklarında söylenmiş ve içerisinde mitik motifli temaların bulunduğu anlatıların bu inanç sistemindeki prestij mitoslarına örnek teşkil ettiği düşünülmektedir.

Tüm bu bilgiler 1şı̆̆ında sonuç olarak şunu söylemek mümkündür: AlevîBektâşîlik inanç sistemi göç etmek zorunda kaldığı bölgelerdeki coğrafi şartlar sebebiyle farklı kültür ve uygarlıkların din ve inanç sistemleriyle etkileşim içine girmek zorunda kalmıştır. Anadolu’ya göçler vasıtasıyla ulaşan bu inanç anlayışı

Turkish Academic Research Review - Türk Akademik Araştırmalar Dergisi 
burada İslam'la bağdaşan yönlerini kendi inanç potasında eritmeyi başarmış, neticede kendine özgü bir inanç anlayışını meydana getirmiştir. Şüphesiz bu senkretik yapının oluşmasında en önemli faktör olarak karşımıza mitik unsurlar çıkmaktadır. Çalışmamızda da belirtildiği gibi Alevî-Bektâş̧iliğin tarihi gelişim süreci incelendiği zaman karşımıza çok katmanlı bir mitik yapıyla karşılaşılmaktadır. Bu mitik yapının özüne inildikçe adeta birbirine geçmiş ve birbirinden bağımsız düşünülmeyen bir zincir halkası çıkmaktadır. Bu durum AlevîBektâşilik ile ilgili araştırma yapan bilim insanlarının üzerinde pek durmadığı, inceleme bekleyen bir araştırma konusu olarak karşımıza çıkmaktadır. Zira geçmişten bu yana gerek yazilı gerekse sözlü kültür yoluyla günümüze ulaşmaya başarabilen Alevî-Bektâşî mitik unsurlarının bu inanç sisteminin oluşumun sürecinde temel dinamikler olduğu görülmektedir. Çalışmamızda ortaya çıkan sonuçlar çerçevesinde denilebilir ki Alevî-Bektâşilik inanç sisteminizdeki tespit edilen mitolojik unsurlar bu inanç sisteminin sadece inançsal boyutunda değil sosyal yaşamın her sahasında etkili olmuştur.

\section{Kaynakça}

Alkan, E. (2005). Sayılar ve Hayvan Simgeleriyle Alevi Mitolojisi, İstanbul: Kaynak Yayınları.

Armutak, A. (2005). Doğu ve Batı Mitolojilerinde Hayvan Motifi I. Memeli Hayvanlar, İstanbul Üniversitesi Veterinerlik Fakültesi Dergisi, 28, ss. 412-413.

Arslanoğlu, İ. (1999a). Cibali Ocağı ve Taliplerinin Alevilikle İlgili Görüşleri, Hacı Bektaş Veli Araştırma Dergisi, 99/12, ss. 115-138.

Arslanoğlu, İ. (1999b).“Türabi Ocağı Dedeleri İle Görüşme”. Hacı Bektaş Veli Araştırma Dergisi, 99 /11, ss.93-108. Yayınları.

Atalay, A. A. (2015). Abdal Musa Sultan ve Velayetnamesi, İstanbul: Can Yayınları.

Attar, F. (1998). Mantıku't-tayr, Ter. Yaşar Keçeci, İstanbul: Kırkambar

Belli, G. S.- Belli, O. (2012). Kars Bölgesinde Kaz Kültürü, İstanbul: Belli Eğitim Kültür Tarih ve Arkeoloji Araştırma Merkezi Yayınları.

Beydilli, C. (2015). Türk Mitolojisi Ansiklopedik Sözlük, çev. Eren Ercan, Ankara: Yurt Kitap Yayınları.

Bozkurt, F. (1995). Semahlar, İstanbul: Cem Yayınları.

Boztemir, E. (2013). Alevi-Bektaşi Şiirlerinde Mitolojik Ögeler 20. yy. Örneği, Yayınlanmamış Yüksek Lisans Tezi, Fatih Üniversitesi Sosyal Bilimler Enstitüsü, İstanbul,

Cıblak, N. (2003). Mersin Tahtacı Kültüründeki Terimler Üzerine Deneme, Folklor/Edebiyat Dergisi, 9 , ss. 217-238.

Çoruhlu, Y.(2002). Türk Mitolojisinin Anahtarı, İstanbul: Kabalcı Yayınevi.

Dağtaşoğlu, A. E. (2014). Anadolu Türkülerinde Yılan Motifi ve Nefs, Yılan Kitab1, ed. Emine Gürsoy Naskali, İstanbul: Kitabevi Yayınları, ss.134-168. Yayınları.

Danık, E. (2006). Öteki Tanrılar Alevi-Bektaşi Mitolojisi, Ankara: İmge

Demirdağ, M. F. (2017). Alevi-Bektaşi Şiirlerinde Kuş Motifi, KÜLLIYAT Osmanlı Araştırmaları Dergisi, 2, ss. 12-18.

Turkish Academic Research Review - Türk Akademik Araştırmalar Dergisi 
Elçin, Ş. (2003). Türk Halk Edebiyatında Turna Motifi, Türk Kültürü ve Hacı Bektaş Veli Araştırma Dergisi, 28, ss.43-59.

Er, P. (2014). Yaşayan Alevilik, Ankara: Barış Kitabevi.

Ergun, P. (2011). Alevilik-Bektaşilikteki Tavşan İnancının Mitolojik Kökleri Üzerine, Türk Kültürü ve Hacı Bektaş Veli Araştırma Dergisi, 60, ss.281-312. Yayınları.

Eröz, M. (1977). Türkiye'de Alevilik Bektaşilik, İstanbul: Otağ Matbaacılık

Gölpınarlı, A. (2017). Menakıb-1 Hacı Bektaş-1 Veli Vilayet-name, İstanbul: İnklap Kitabevi. Yayınları.

Gölpınarlı, A.- Boratov, P. N. (2017). Pir Sultan Abdal, İstanbul: Kapı

Güngör, Ö.-Aksoy, A. (2012). Sosyolojik Açıdan Alevi/Bektaşilerde Tenasüh İnanc1, Türk Kültürü ve Hacı Bektaş Veli Araştırma Dergisi, 62, ss. 249-270.

Günşen, A. (2007). Gizli Dil açısından Alevi-Bektaşilik Erkan ve Deyimlerine Bir Bakış, Turkish Studies, 2/2, ss. 328-350. Basımevi.

Güzel, A. (1999). Abdal Musa Velayetnamesi, Ankara: Türk Tarih Kurumu

Harman, M. (2014). İnsan-1 Kâmil Yazı Resimlerinin İkonografik ve Sembolik Anlamlarına Dair Bir Çözümleme, Türk Kültürü ve Hacı Bektaş Veli Araştırma Dergisi, 70, ss. 97-119. Yayınları.

Kirman, M.A. (2011). Din Sosyolojisi Terimler Sözlüğü, İstanbul: Rağbet

Korkmaz, E. (1996). Pir Sultan Abdal Divanı, İstanbul: Ant Yayınları.

Kotle, T. (2010). Arnavutluk-Balkanlarda Bektaşilik, Turan Stratejik Araştırma Dergisi, 5, ss.24-28.

Kuşca, S. (2014). Şah İsmail Hatai'nin ve Pir Sultan Abdal'ın Nefes ve Deyilerinde Mitik Unsurlar. Yayınlanmamış Yüksek Lisans Tezi, Eskişehir Osmangazi Üniversitesi, Sosyal Bilimler Enstitüsü, Eskişehir.

Melikoff, I.(1999). Hacı Bektaş Efsaneden Gerçeğe, çev. Turan Alptekin, İstanbul: Çınar Ofset Matbaacılık.

Melikoff, I. (2015). Uyur idik Uyardılar, çev. Turan Alptekin, İstanbul: Demos Yayınları.

Noyan, B. (2010). Bütün Yönleriyle Bektaşilik ve Alevilik VIII. Cilt, Ankara: Ardıç Yayınları.

Ocak, A. Y. (2017). Alevî-Bektaşî İletişim İnançlarının İslam Öncesi Temelleri, İstanbul: İletişim Yayınları.

21.

Ölmez, F. N. (2010). Dokumalarda Yılan Motifi, Art-e Sanat Dergisi, 6, ss.2-

Roux, J. P. (1997). Türk İnancında Tavşan, Yabancı Araştırmacılar Gözüyle Alevilik Tuttum Aynayı Yüzüme Ali Göründü Gözüme, Çev. İlhan Cem Erseven, İstanbul: Ant Yayınlar1, ss.64-77.

Sax, B. (2006). Toplumun Aynasında Karga, çev. Banu Büyükal, İstanbul: Kitap Yayınevi.

Turkish Academic Research Review - Türk Akademik Araştırmalar Dergisi 
Schimmel, A. (2004). Tanrı'nın Yeryüzündeki İşaretleri (İslama Görüngebilimsel Yaklaşım), çev. Mustafa Küpüşoğlu, İstanbul: Kabalcı Yayınevi.

Selçuk, A. (2008). Ağaçeri Türkmenleri Tahtacılar, İstanbul: IQ Kültür Sanat Yayıncilık. Yayınları.

Seyidoğlu, B. (2002). Mitoloji Üzerine Araştırmala,. İstanbul: Dergâh

Su, S. (2011). Hurafeler ve Mitler - Halk İslâmında Senkretizm, İstanbul: İletişim Yayınları.

Tanyu, H. (1987). Türklerde Taşla İlgili İnanışlar, Ankara: Kültür ve Turizm Bakanlığı Yayınları.

Taşğın, A.-Solmaz, B. (2012). "Hacı Bektaş ve Hacı Toğrul Karşılaşması: Güvercin ve Doğan Donuna Bürünme”, Turkish Studies, 7/1, ss.105-129.

Tekin, N. (2011). Türklük ve Alevilik-Bektaşilik, İstanbul: İlgi Yayınları.

Uçar, R. (2012). Alevîlik-Bektaşîlik Abdal Musa Tekkesi Üzerine Sosyolojik Bir Araştırma, Ankara: Berikan Yayınevi.

Uraz, M. (1992). Türk Mitolojisi, İstanbul: Mitologya Yayınları.

Yıldız, H. (2014). Anadolu Aleviliği (Amasya Yöresi Bağlamında Bir İnceleme), Ankara: Ankara Okulu Yayınları.

Turkish Academic Research Review - Türk Akademik Araştırmalar Dergisi 